\title{
Inhaled corticosteroids in COPD: a light at the end of the tunnel?
}

\section{J A Wedzicha, T A R Seemungal}

\section{Some promising findings on the effects of inhaled corticosteroids on mortality in COPD}

$C^{2}$ hronic obstructive pulmonary disease (COPD) is arguably the most common chronic disease of the lungs at present and, by 2020, it will be the third leading cause of death worldwide. ${ }^{1}$ COPD is associated with a relentless decline in forced expiratory volume in 1 second $\left(\mathrm{FEV}_{1}\right)$ and, in the later stages, the condition progresses to pulmonary hypertension and hypoxic respiratory failure.

Few interventions have been shown to affect the outcome of COPD. The Lung Health Study-1 (LHS-1) showed that smoking cessation decreases the accelerated decline in $\mathrm{FEV}_{1}$ characteristic of this disease ${ }^{2}$ and, more recently, that smoking cessation is associated with decreases in cardiovascular and lung cancer mortality in patients with COPD. ${ }^{3}$ Furthermore, two randomised controlled studies of long term oxygen therapy (LTOT) showed that LTOT improves mortality in patients with COPD complicated by hypoxic respiratory failure. ${ }^{45}$

Because so few interventions have been shown to affect mortality and $\mathrm{FEV}_{1}$ decline in COPD, two further outcomes have been studied arising from the observed close association between exacerbation frequency and health related quality of life. ${ }^{6}$ In the ISOLDE study (Inhaled corticosteroids in Obstructive Lung Disease in Europe), inhaled corticosteroids were shown to slow the decline in health status over time and also to decrease exacerbation frequency. ${ }^{7}$ Further statistical modelling has shown that the effect of inhaled corticosteroids on quality of life is largely due to their effect on exacerbation frequency. ${ }^{8}$ Recent studies have closed the loop between exacerbation frequency, mortality, and lung function decline by showing that patients with a history of frequent exacerbations have an accelerated decline in $\mathrm{FEV}_{1}{ }^{910}$ and increased mortality from COPD. ${ }^{11}$ From these data one would therefore expect that interventions that reduce COPD exacerbations would also reduce COPD mortality. study by Sin and colleagues who show, for the first time, that inhaled corticosteroids are associated with a reduction in all-cause mortality in patients with COPD. ${ }^{12}$ This study is important for several reasons. Firstly, it represents a major collaboration between academia and industry that allowed a pooled analysis of the original data from all seven longer term randomised controlled studies of the effects of inhaled corticosteroids in COPD. ${ }^{73-18}$ This is a major strength of this study. Secondly, it is one of the few studies to report an intervention that affects all-cause mortality in COPD. Thirdly, this study shows that COPD mortality may be affected before developing end stage disease in COPD. A previous systematic review found no significant effect of inhaled corticosteroids on mortality but confirmed the beneficial effects of inhaled corticosteroids on exacerbation frequency. ${ }^{19}$ A recent meta-analysis of eight studies of inhaled corticosteroids (four of which are included in the current report) showed that inhaled corticosteroids decreased the decline in $\mathrm{FEV}_{1},{ }^{20}$ perhaps through their effect on exacerbations. Thus, before the report of Sin and colleagues, the major effect of inhaled corticosteroids in COPD was considered to be on reduction in exacerbations with no clear effect on mortality.

The authors obtained the original anonymised data from each of the seven randomised placebo controlled trials of inhaled corticosteroids of at least 12 months duration. ${ }^{7}{ }^{13-18}$ The data were then pooled to form a dataset of 5085 patients with allowance for source effect. The study design is unique, and the authors should be commended for their contribution and effort in this regard. Sin and colleagues showed that inhaled corticosteroids reduced allcause mortality by $27 \%$, and the effects were more pronounced in women, former smokers, and patients with moderate or severe disease. Sex differences in the natural history of COPD have been recognised for some time, with women showing a faster decline in $\mathrm{FEV}_{1}{ }^{21}$
In this issue of Thorax we publish a
However, as Sin and colleagues point out in the discussion to the paper, women with COPD have greater bronchial hyperreactivity than $\operatorname{men}^{22}$ and this factor may be associated with the observation that the effects of inhaled corticosteroids on mortality are more pronounced in women. Further studies are required to confirm these sex differences and to investigate the mechanisms associated with these observations.

As with all post hoc analyses of this type, there are limitations. Firstly, only two of the studies (ISOLDE and LHS-2) included mortality on an intention to treat basis, while in the other five studies mortality data were only available for those who completed the study. ${ }^{7}{ }^{13}$ These two studies contributed $37 \%$ of the patients to the analysis and were also the two longest studies (34 and 42 months, respectively). The effect of ISOLDE and LHS-2 are therefore likely to influence the results more than the other included studies. The contribution of each study to the overall death rate is not shown in the report and the authors refer to this possible source of bias in their discussion. There are also differences in the pre-intervention treatment of patients between the different studies. For example, in the EUROSCOP study ${ }^{15}$ there was a 6 month run-in with no treatment but the ISOLDE study and the study by Calverley and colleagues ${ }^{7}{ }^{17}$ included a run-in period during which patients were treated with oral corticosteroids. Furthermore, the size of the included studies varied because they were each powered to detect different parameters. For example, four of the seven studies were powered to detect a difference in the decline in $\mathrm{FEV}_{1}$ of $12-$ $20 \mathrm{ml} /$ year between inhaled corticosteroids and placebo controlled groups ${ }^{73-15}$ and all failed to detect a difference, but the meta-analysis by Sutherland et al ${ }^{20}$ showed that this difference was in fact much smaller-of the order of $7.7 \mathrm{ml} /$ year. Finally, in all the included studies the difficulty in finding an effect on mortality hitherto has been because of the effect of dropouts. In a further analysis from the ISOLDE study, Calverley and colleagues showed that dropouts were greater in the placebo arm and were associated with a faster decline in $\mathrm{FEV}_{1}$, thus implying that mortality was probably greater in the placebo arm, ${ }^{23}$ which has now been supported by Sin et al. ${ }^{12}$

Currently, for patients with COPD, it may no longer be relevant to ask whether inhaled corticosteroids have a role, but the question still remains-which COPD patients should be given inhaled corticosteroids? The ISOLDE study showed that the effects of inhaled corticosteroids on exacerbation frequency were greatest 
for patients with an $\mathrm{FEV}_{1}$ of $<50 \%$ predicted. $^{7}$ But the LHS-2 found a 50\% decrease in unscheduled physician visits for respiratory illnesses (interpreted as exacerbations) in patients with much milder COPD. ${ }^{13}$ A further analysis from the ISOLDE study showed that, when patients with an exacerbation frequency of at least one per year are studied, the effects of inhaled corticosteroids on the reduction of exacerbations are also present in patients with milder COPD. ${ }^{8}$ The study by Sin et al found that the effect of inhaled corticosteroids on COPD mortality was statistically significant in patients with $\mathrm{FEV}_{1}<60 \%$ but not in those with a higher $\mathrm{FEV}_{1}$, although we must be careful about subset analysis in a pooled dataset such as this-and the authors have cautioned us appropriately in the paper. ${ }^{12}$ However, one of the further important questions that arises from this study and others is the actual dose of inhaled corticosteroids that should be prescribed in COPD and the long term side effects of this dosage.

Inhaled corticosteroids have similar effect sizes on $\mathrm{FEV}_{1}$ decline in COPD and on exacerbations $(7.7 \mathrm{ml} / \mathrm{year}$ is about $25 \%$ of the expected $\mathrm{FEV}_{1}$ decline in normal patients, ISOLDE found a $25 \%$ effect on reduction in exacerbation frequency). The effect of inhaled corticosteroids on mortality in patients with COPD may therefore be through decreased exacerbation frequency.

Intriguingly, Sin and colleagues in their meta-analysis found a trend towards a lower incidence of cancer mortality in the treatment arm; however, cancer deaths in this study were low and the study was not powered to look at specific causes of death. A further larger study is therefore required before clear conclusions can be drawn about the effects of inhaled corticosteroids on specific causes of mortality.

Twelve years ago, one of us writing an editorial in this journal made the point that, despite much work on the role of inhaled corticosteroids in COPD, the results of larger controlled trials of the effects of inhaled corticosteroids on $\mathrm{FEV}_{1}$ decline and disease progression were keenly awaited. ${ }^{24}$ We now recognise that one of the major effects of inhaled corticosteroids in COPD may be through the reduction in the frequency and severity of exacerbations and thus decreasing mortality. In addition to leading to respiratory failure and mortality in more severe disease, COPD exacerbations are associated with increased systemic inflammatory markers such as plasma fibrinogen and C-reactive protein (CRP), so patients with a history of frequent exacerbations may have an increased risk of cardiovascular disease. ${ }^{25} 26$ A reduction in exacerbation frequency in patients with COPD may therefore lead not only to improvements in health status, disease progression and respiratory mortality, but also to a reduction in cardiovascular morbidity and mortality. We now await the results of the TORCH (TOwards a Revolution in COPD Health) study of the long term effects of inhaled corticosteroids and long acting bronchodilators (alone and in combination) on mortality in COPD in one of the largest prospective studies ever undertaken on the treatment of COPD - the TORCH light that will now perhaps guide us to the end of the tunnel? ${ }^{27}$

Thorax 2005;60:977-978.

doi: 10.1136/thx.2005.053454

\section{Authors' affiliations}

J A Wedzicha, Professor of Respiratory Medicine, Royal Free and University College Medical School, University College London T A R Seemungal, Senior Lecturer, University of West Indies, St Augustine Campus, Trinidad

Correspondence to: Professor J A Wedzicha, Royal Free and University College Medical School, Rowland Hill Street, Hampstead, London NW3 2PF, UK; j.a.wedzicha@medsch. ucl.ac.uk

Competing interests: In the last 3 years JAW has obtained research funding for studies of COPD exacerbations from Glaxo Smith Kline, Astra Zeneca, Boehringer Ingelheim and Aventis Pasteur. She has also received honoraria for lectures or attending advisory boards from Glaxo Smith Kline, Astra Zeneca, Boehringer Ingelheim, Pfizer, Aventis Pasteur, Bayer, Novartis, and Arrow Therapeutics Ltd. TARS has obtained sponsorship to attend international meetings from Glaxo Smith Kline, Astra Zeneca, Boehringer Ingelheim, Pfizer and Merck Sharpe \& Dohme and has received honoraria for lectures at meetings organised by all five companies.

\section{REFERENCES}

1 Murray CJL, Lopez AD. Global mortality, disability, and the contribution of risk factors: Global Burden of Disease Study. Lancet 1997;349: 1436-42.

2 Anthonisen NR Connett JE, Kiley JP, et al. Effects of smoking intervention and the use of an inhaled anticholinergic bronchodilator on the rate of decline of $\mathrm{FEV}_{1}$. The Lung Health Study. JAMA 1994; 16:1539-41.

3 Anthonisen NR, Skeans MA, Wise RA, et al. Lung Health Study Research Group. The effects of a smoking cessation intervention on 14. 5-year mortality: a randomized clinical trial, Ann Intern Med 2005; 142:233-9.

4 Nocturnal Oxygen Therapy Trial Group. Continuous or nocturnal oxygen therapy in hypoxaemic chronic obstructive lung disease. Ann Intern Med 1980;93:391-8

5 Medical Research Council Working Party. Longterm domiciliary oxygen therapy in chronic hypoxic cor pulmonale complicating chronic bronchitis and emphysema. Lancet 1981 ; i:681-6.

6 Seemungal TAR, Donaldson GC, Paul EA, et al. Effect of exacerbation on quality of life in patients with chronic obstructive pulmonary disease. Am J Respir Crit Care Med 1998;157:1418-22.
7 Burge PS, Calverley PMA, Jones PW, et al. Randomised, double blind, placebo controlled study of fluticasone propionate in patients with moderate to severe chronic obstructive pulmonary disease: the ISOLDE trial. BMJ 2000;320: 1297-303.

8 Spencer S, Calverley PMA, Burge PS, et al. Impact of preventing exacerbations on deterioration of health status in COPD. Eur Respir J 2004:23:1-5.

9 Donaldson GC, Seemungal TAR, Bhowmik A, et al. Relationship between exacerbation frequency and lung function decline in chronic obstructive pulmonary disease. Thorax 2002;57:847-52.

10 Kanner RE, Anthonisen NR, Connett J, for the Lung Health Study. Lower respiratory illnesses promote $\mathrm{FEV}_{1}$ decline in smokers but not exsmokers with mild chronic obstructive pulmonary disease: results from the Lung Health Study. Am J Respir Crit Care Med 2001;164:358-64.

11 Soler-Cataluña JJ, Martínez-García MA, Román Sánchez $\mathrm{P}$, et al. Severe acute exacerbations and mortality in patients with chronic obstructive pulmonary disease. Thorax 2005;60:925-31

12 Sin DD, Wu L, Anderson JA, et al. Inhaled corticosteroids and mortality in chronic obstructive pulmonary disease. Thorax 2005;60:992-7.

13 Lung Health Study Research Group. Effect of inhaled triamcinolone on the decline in pulmonary function in chronic obstructive pulmonary disease. N Engl J Med 2000;343:1902-9.

14 Vestbo J, Sorenson T, Lange $\mathrm{P}$, et al. Long term effect of inhaled budesonide in mild and moderate mild chronic obstructive pulmonary disease: a randomised controlled trial. Lancet 1999;353:1819-23.

15 Pauwels RA, Lofdahl C-G, Laitinen LA, et al. Long term treatment with inhaled budesonide in persons with mild chronic obstructive pulmonary disease. N Engl J Med 1999;340:1819-23.

16 Calverley PMA, Pauwels R, Vestbo J, for the Tristan Study Group, et al. Combined Salmeterol and fluticasone in the treatment of chronic obstructive pulmonary disease: a randomised controlled trial. Lancet 2003;361:449-56.

17 Calverley PM, Boonsawat W, Cseke Z, et al. Maintenance therapy with budesonide and formoterol in chronic obstructive pulmonary disease. Eur Respir J 2003;22:912-8.

18 Szafranski W, Cukier A, Ramirez A, et al. Efficacy and safety of budesonide/formoterol in the management of chronic obstructive pulmonary disease. Eur Respir J 2003;21:74-81.

19 Alsaeedi A, Sin DD, McAlister FA. The effects of inhaled corticosteroids in chronic obstructive pulmonary disease: a systematic review of randomised placebo-controlled trials. Am J Med 2002; 113:59-65.

20 Sutherland ER, Allmers H, Ayas NT, et al. Inhaled corticosteroids reduce the progression of airflow limitation in chronic obstructive pulmonary disease: a meta-analysis. Thorax 2003;58:937-41.

21 Watson L, Vonk JM, Lofdahl CG, et al. Predictors of lung function and its decline in mild to moderate COPD in association with gender: results from the EUROSCOP study. Respir Med 2005 September 29 (epub ahead of print).

22 Kanner RE, Connett JE, Altose MD, et al. Gender difference in airway hyperresponsiveness in smokers and mild COPD. The Lung Health Study. Am J Respir Crit Care Med 1994;150:956-61.

23 Calverley PMA, Spencer S, Burge, et al, on behalf of the ISOLDE study group. Withdrawing from treatment as an outcome in chronic obstructive pulmonary disease. Chest 2003;124:1350-6.

24 Wedzicha JA. Inhaled corticosteroids in COPD: awaiting controlled trials. Thorax 1993;48:305-7.

25 Wedzicha JA, Seemungal TAR, MacCallum PK, et al. Acute exacerbations of chronic obstructive pulmonary disease are accompanied by elevations of plasma fibrinogen and serum IL-6 levels. Thromb Haemost 2000;84:210-5.

26 Donaldson GC, Seemungal TAR, Patel IS, et al. Airway and systemic inflammation and decline in lung function in chronic obstructive pulmonary disease. Chest 2005 (in press).

27 Vestbo J, TORCH Study Group. The TORCH (TOwards a Revolution in COPD Health) survival study protocol. Eur Respir J 2004;24:206-10. 
$\mathrm{PaCO}_{2}$. This is attributed to the heating effect of the electrode. Nevertheless, strong correlations have been observed between $\mathrm{TCCO}_{2}$ and $\mathrm{PaCO}_{2}$ values and between changes in $\mathrm{TcCO}_{2}$ and in $\mathrm{PaCO}_{2} \cdot{ }^{10}$

The third difficulty concerns the other indications for nocturnal NIV. As previously discussed, the indication is usually based on a cut-off $\mathrm{PaCO}_{2}$ value which is transgressed during a defined percentage of the sleep time or the study period. But other respiratory events during sleep-for example, those recently recommended for the diagnosis of sleep related breathing disorders ${ }^{11}$ such as sleep fragmentation-may also need to be taken into account. Moreover, it may be possible that the optimal definition of nocturnal hypoventilation differs according to the underlying disease and also in children compared with adults. A definition based exclusively on the $\mathrm{PCO}_{2}$ value may be too restrictive and insufficiently relevant from a clinical perspective.

If NIV is proposed earlier in the course of ventilatory failure, it should be accompanied by a significant improvement in measurable symptoms attributable to nocturnal hypoventilation, disruption of sleep architecture, and poor quality of sleep. NIV is able to improve nocturnal gas exchange in patients with neuromuscular disease, cystic fibrosis, ${ }^{12}{ }^{13}$ and obstructive sleep apnoea, both in adults and children. ${ }^{14}$ But, in all these studies, patients had overt daytime hypoventilation. NIV initiated according to the "classical criteria" was associated with an improvement in survival in patients with Duchenne muscular dystrophy, ${ }^{15} 16$ but the only study that has evaluated the "preventive" use of NIV in patients with Duchenne muscular dystrophy showed negative results with a significantly greater mortality rate in the NIV group. ${ }^{17}$ In this study the main inclusion criteria were a vital capacity of $20-50 \%$ of the predicted value and a $\mathrm{PaCO}_{2}$ value below $6 \mathrm{kPa}$. The patients did not undergo polysomnography before and after the initiation of NIV and no information was given on the symptoms attributable to sleep disordered breathing. Patients with a variable level of nocturnal hypoventilation could therefore have been included without a control to determine the efficacy of NIV and an objective measure of compliance with its use. This argues for a more precise evaluation of subjective measures (such as symptoms) and objective measures of sleep disordered breathing before initiation of NIV.

In addition to an improvement in nocturnal hypoventilation and survival, it would be highly desirable if the use of 
"early" NIV was also associated with a significant decrease in acute exacerbations and, in patients with neuromuscular disease and cystic fibrosis, with a slowing in the decrease in lung function and respiratory muscle performance. A delay in acute exacerbations has not been observed in neuromuscular patients and would be very difficult to prove in patients with cystic fibrosis. NIV seems to be associated with a slower rate of decline in pulmonary function in patients with Duchenne muscular dystrophy compared with control subjects, ${ }^{15}$ and in children with various neuromuscular disorders. ${ }^{19}$ However, in cystic fibrosis, such data are not yet available. In children, particularly those with neuromuscular disorders, it would be interesting to examine whether "early" NIV is associated with better lung growth. Indeed, mechanical forces generated by the contractile activity of the diaphragm and the intercostal muscles have been shown to play an important part in normal lung growth and development in animal models by their effect on cell proliferation. ${ }^{20} 21$

Two other major aspects of NIV have been poorly studied. Sleep disordered breathing causes impaired cognitive function and is associated with a poor quality of life. These adverse effects may affect the patient's daily life and the school performances of a child before the occurrence of daytime hypercapnia. Studies of the effect of "early" initiation of NIV should evaluate these outcomes according to the underlying disease and the age of the patient.

In conclusion, having established that NIV can reverse alveolar hypoventilation in patients with neuromuscular and lung disease, the time has come to evaluate, for each disease, the optimal timing for polysomnography - the most pertinent indicator for proposing NIVand to evaluate its benefits with regard to the course of the disease, stabilisation of lung function and respiratory muscle performance, improvement in cognitive functioning, possible preservation of lung growth in young children and, most importantly, the quality of life of the patient and his/her family.

Thorax 2005;60:979-980.

doi: 10.1136/thx.2005.040394

\section{Authors' affiliations}

B Fauroux, Pediatric Pulmonary Department and INSERM U719, Armand Trousseau Hospital, Assistance Publique - Hôpitaux de Paris, Garches, France

F Lofaso, Physiology Department, Raymond Poincaré Hospital, Assistance Publique Hôpitaux de Paris, Garches, France

Correspondence to: Professor B Fauroux, Pneumologie Pédiatrique and Research Únit INSERM U719, Hôpital d'Enfants Armand Trousseau, Assistance Publique - Hôpitaux de Paris, 75571 Paris Cedex 12, France; brigitte. fauroux@trs.ap-hop-paris.fr

\section{REFERENCES}

1 Robert D, Willig TN, Paulus J. Long-term nasal ventilation in neuromuscular disorders: report of a Consensus Conference. Eur Respir J 1993;6:599-606.

2 Rutgers M, Lucassen H, Kesteren RV, et al. Respiratory insufficiency and ventilatory support. 39th European Neuromuscular Centre International workshop. Neuromusc Disord 1996:6:431-5.

3 ATS Consensus Conference. Respiratory care of the patient with Duchenne muscular dystrophy. Am J Respir Crit Care Med 2004; 170:456-65.

4 Lofaso F, Quera-Salva MA. Polysomnography for the management of progressive neuromuscular disorders. Eur Respir J 2002;19:989-90.

5 Hukins CA, Hillman DR. Daytime predictors of sleep hypoventilation in Duchenne muscular dystrophy. Am J Respir Crit Care Med 2000;161:166-70.

6 Bye PTP, Ellis ER, Issa FG, et al. Respiratory failure and sleep in neuromuscular disease. Thorax 1990:45:241-7.

7 Ward S, Chatwin M, Heather S, et al. Randomised controlled trial of non-invasive ventilation (NIV) for nocturnal hypoventilation in neuromuscular and chest wall disease patients with daytime normocapnia. Thorax 2005;60:1019-24.

8 Bourke SC, Gibson GJ. Sleep and breathing in neuromuscular diseases. Eur Respir J 2002; 19:1194-201.

9 Hart N, Polkey MI, Clément A, et al. Changes in pulmonary mechanics with increasing disease severity in children and young adults with cystic fibrosis. Am J Respir Crit Care Med 2002;166:61-6.

10 Hanly PH. Transcutaneous monitoring of carbon dioxide. In: Tobin MJ, ed. Principles and practices of intensive care monitoring. Paris: McGraw Hill, 1997:401-14.

11 American Academy of Sleep Medicine. Sleeprelated breathing disorders in adults: recommendations for syndrome definition and measurement techniques in clinical research. Sleep 1999;22:667-89.

12 Gozal D. Nocturnal ventilatory support in patients with cystic fibrosis: comparison with supplemental oxygen. Eur Respir J 1997; 10:1999-2003.

13 Milross MA, Piper AJ, Norman M, et al. Low-flow oxygen and bilevel ventilatory support. Effects on ventilation during sleep in cystic fibrosis. Am J Respir Crit Care Med 2001;163:129-34.

14 Fauroux B, Pigeot J, Polkey MI, et al. Chronic stridor caused by laryngomalacia in children. Work of breathing and effects of noninvasive ventilatory assistance. Am J Respir Crit Care Med 2001; 164:1874-8

15 Simonds A, Muntoni F, Heather S, et al. Impact of nasal ventilation on survival in hypercapnic Duchenne muscular dystrophy. Thorax 1998;53:949-52.

16 Jeppesen J, Green A, Steffensen BF, et al. The Duchenne muscular dystrophy population in Denmark, 1977-2001: prevalence, incidence and survival in relation to the introduction of ventilator use. Neuromusc Disord 2003; 13:804-12.

17 Raphael J, Chevret S, Chastang C, et al Randomised trial of preventive nasal ventilation in Duchenne muscular dystrophy. Lancet 1994;343: 1600-4

18 Barbé F, Quera-Salva MA, de Lattre J, et al. Long-term effects of nasal intermittent positivepressure ventilation on pulmonary function and sleep architecture in patients with neuromuscular disease. Chest 1996;110:1179-83.

19 Mellies U, Ragette R, Dohna Schwake C, et al. Long-term noninvasive ventilation in children and adolescents with neuromuscular disorders. Eur Respir J 2003;22:631-6.

20 Inanlou MR, Kablar B. Abnormal development of the diaphragm in mdx:Myo-/-9th embryos leads to pulmonary hypoplasia. Int $J$ Dev Biol 2003;47:363-71.

21 Inanlou MR, Kablar B. Abnormal development of the intercostal muscles and the rib cage in Myf5-/- embryos leads to pulmonary hypoplasia. Dev Dyn 2005;232:43-54. 
Improving survival in idiopathic $\mathrm{PAH}$

\section{Improving survival in idiopathic pulmonary arterial hypertension: revisiting the "kingdom of the near- dead" $^{\prime \prime}$}

\author{
S Mehta, G J Shoemaker
}

Recent advances in the treatment of idiopathic PAH have resulted in increased survival

diopathic pulmonary arterial hypertension (PAH), formerly known as primary pulmonary hypertension, is characterised by raised pulmonary artery pressure and pulmonary vascular resistance in the absence of underlying significant cardiopulmonary or other medical disease. Idiopathic PAH is a progressive disorder that usually culminates in right ventricular failure and death. Moreover, patients with idiopathic $\mathrm{PAH}$ are often severely limited on exertion by dyspnoea and fatigue, and thus suffer from a poor quality of life.

Despite clinical recognition of idiopathic PAH for more than 100 years, there have been few effective therapeutic options until recently. Given the previous absence of effective pharmacological therapy, surgical removal of the disease by lung transplantation has been an important therapeutic option for patients with idiopathic PAH. Lung transplantation is associated with rapid and sustained improvement in pulmonary haemodynamics. ${ }^{1}$ Moreover, in individual patients with idiopathic PAH who do not respond to medical treatment, timely lung transplantation will often be associated with improved survival even though long term survival after lung transplantation remains poor. ${ }^{23}$

One of the first long term pharmacological approaches used for treating idiopathic PAH was systemic anticoagulation. In patients with idiopathic PAH, pulmonary microvascular thrombosis is present histologically and there is laboratory evidence of a procoagulant haematological state. ${ }^{45}$ Moreover, both retrospective and non-randomised cohort studies have suggested a survival benefit of systemic anticoagulation in idiopathic PAH. ${ }^{67}$ Although not formally studied in a randomised controlled trial, systemic anticoagulation is recommended for the majority of patients with PAH in the absence of a clear contraindication based on assessment of individual bleeding risk. ${ }^{8}$

\section{SURVIVAL BENEFIT OF NEW TREATMENTS IN IDIOPATHIC PAH}

Ongoing basic biological and clinical research has led to tremendous advances in our understanding of the pathobiology of idiopathic PAH. Moreover, an increasing number of novel therapeutic agents targeting these pathobiological features have been studied in randomised clinical trials and for clinical use in patients with idiopathic PAH. These include prostacyclin derivatives such as intravenous epoprostenol, subcutaneous treprostinil, inhaled iloprost, and oral beraprost, as well as other novel oral pulmonary hypertension treatments such as the non-selective endothelin receptor antagonist bosentan and the phosphodiesterase $\mathrm{V}$ inhibitor sildenafil..$^{8-13}$

These new treatments for pulmonary hypertension have been shown to improve pulmonary haemodynamics as well as clinically relevant end points such as symptoms and functional capacity, objectively measured exercise capacity, and quality of life in many patients with idiopathic PAH. But are such improvements in the morbidity associated with idiopathic PAH enough? Most would agree that improvements in symptoms and functional capacity should not be the only goals. Patients with idiopathic PAH, a disease which is usually fatal, have been suggested to live in a "kingdom of the near-dead". ${ }^{14}$ An improvement in survival has therefore always been an important goal of treatment for both patients and their caregivers.

A significant survival benefit has been suggested in patients with idiopathic PAH treated with several agents including oral calcium channel blockers, intravenous epoprostenol, oral beraprost, and oral bosentan (table 1). Chronic treatment with high dose calcium channel blockers was the first to show a survival benefit in these patients. ${ }^{7}$ Although treatmany are available and recommended ment of idiopathic PAH with calcium channel blockers has not been assessed in a randomised controlled trial, high dose calcium channel blockers are accepted as first line oral treatment for some patients with idiopathic PAH based on the dramatic survival benefit observed in a nonrandomised cohort trial and long term clinical experience. ${ }^{75}$ Unfortunately, only a minority of patients with idiopathic PAH (13-27\%) demonstrate acute vasodilator responsiveness. ${ }^{715}$ Moreover, sustained long term reductions in pulmonary arterial pressure may only be achieved with high dose calcium channel blockers in perhaps half of acute vasodilator responders, ${ }^{15}$ so only $7-15 \%$ of patients with idiopathic PAH may have improved survival with chronic calcium channel blocker treatment.

For the large majority of idiopathic PAH patients who are not candidates for long term treatment with calcium channel blockers, an increasing number of therapeutic agents are becoming available. In such patients the first alternative was continuous intravenous delivery of epoprostenol. In a landmark study, ${ }^{9}$ intravenous epoprostenol treatment was associated with a significant survival benefit compared with standard treatment, although survival was not the primary end point. Several groups have recently published their long term experience confirming a survival benefit of intravenous epoprostenol treatment. ${ }^{16-18}$ A small retrospective study suggests a survival benefit of an oral prostacyclin derivative, beraprost. ${ }^{19}$

The report by Sitbon and colleagues in this issue of Thorax supports a long term survival benefit of treatment with bosentan, the first drug in a new class of pharmacological agents, the endothelin receptor antagonists. ${ }^{20}$ Bosentan is the first oral agent specifically approved for treatment of idiopathic PAH in North America, Europe, and other parts of the world. The study by Sitbon et al confirms the survival benefit suggested by an analysis of long term, open label bosentan treatment in idiopathic PAH patients enrolled in the original two randomised controlled trials. ${ }^{21}$

It is apparent that none of the studies of pulmonary hypertension specific treatments were placebo controlled, double blind randomised controlled trials and all suffer from several methodological limitations, some major (table 1). These include a lack of randomisation, non-blinding of patients and investigators to the active treatment, and limited power as many studies assessed fewer than 50 patients. In addition, all studies are limited by either a complete absence of a control group or the use of a control group other than a placebo treated cohort. Moreover, the basis of the survival advantage in 
Table 1 Studies reporting improved survival with pulmonary hypertension specific treatment in patients with idiopathic PAH

\begin{tabular}{|c|c|c|c|c|c|c|c|c|c|c|c|c|c|c|}
\hline \multirow[b]{2}{*}{ Reference } & \multirow[b]{2}{*}{ Treatment } & \multirow{2}{*}{$\begin{array}{l}\text { Active } \\
\text { treatment } \\
\text { group } \\
\text { (n) }\end{array}$} & \multirow{2}{*}{$\begin{array}{l}\text { WHO class } \\
(\mathrm{I} / \mathrm{II} / \mathrm{III} / \mathrm{IV})_{n}\end{array}$} & \multicolumn{5}{|c|}{ Observed survival (\%) } & \multicolumn{5}{|c|}{ Expected/control survival (\%) } & \multirow[b]{2}{*}{ Details/limitations } \\
\hline & & & & $3 m$ & ly & $2 y$ & $3 y$ & $5 y$ & $3 m$ & ly & $2 y$ & $3 y$ & $5 y$ & \\
\hline Rich $^{7}$ & Oral CCB & 17 & N/A & & 94 & & 94 & 94 & & 68 & & 47 & 38 & $\begin{array}{l}\text { Prospective open label cohort; } 17 / 64 \text { patients } \\
\text { selected for chronic CCB based on acute CCB } \\
\text { response; survival with chronic } C C B \text { compared } \\
\text { with acute non-responders }(n=47) \text { and } \mathrm{NIH} \\
\text { Registry cohort }\end{array}$ \\
\hline Sitbon $^{15}$ & Oral CCB & 38 & $0 / 22 / 16 / 0$ & & 100 & 97 & 97 & 97 & & 71 & 66 & 62 & 48 & $\begin{array}{l}\text { Retrospective review of } 70 / 557 \text { patients } \\
\text { selected for chronic CCB based on acute } \\
\text { vasodilator response; survival of chronic CCB } \\
\text { responders ( } n=38 \text { ) compared with chronic } \\
\text { CCB failures ( } n=32 \text { ) }\end{array}$ \\
\hline Barst $^{9}$ & IV epoprostenol & 41 & $0 / 0 / 31 / 10$ & 100 & & & & & 80 & & & & & $\begin{array}{l}\text { Prospective open label RCT; no placebo } \\
\text { infusion; survival not primary end point }\end{array}$ \\
\hline Kuhn $^{18}$ & IV epoprostenol & 41 & $0 / 0 / 19 / 22$ & & 85 & 76 & 65 & & & 62 & 49 & 39 & & $\begin{array}{l}\text { Prospective open label cohort; survival } \\
\text { compared with predicted survival based on } \\
\text { NIH equation }\end{array}$ \\
\hline McLaughlin ${ }^{16}$ & IV epoprostenol & 162 & $0 / 0 / 75 / 87$ & & 88 & 76 & 63 & & & 59 & 46 & 35 & & $\begin{array}{l}\text { Prospective open label cohort; survival } \\
\text { compared with predicted survival based on } \mathrm{NIH} \\
\text { equation }\end{array}$ \\
\hline Sitbon ${ }^{17}$ & IV epoprostenol & 178 & $0 / 0 / 120 / 58$ & & 85 & 70 & 63 & 55 & & 58 & 43 & 33 & 28 & $\begin{array}{l}\text { Prospective open label cohort; survival } \\
\text { compared with WHO matched historical } \\
\text { cohort }(n=135)\end{array}$ \\
\hline Nagaya $^{19}$ & Oral beraprost & 24 & $0 / 0 / 22 / 2$ & & 96 & 86 & 76 & & & 77 & 47 & 44 & & $\begin{array}{l}\text { Retrospective review of single centre } \\
\text { experience; survival compared with WHO } \\
\text { matched historical cohort }(n=34)\end{array}$ \\
\hline McLaughlin ${ }^{21}$ & Oral bosentan & 169 & $2 / 13 / 139 / 15$ & & 96 & 89 & 86 & & & 69 & 57 & 48 & & $\begin{array}{l}\text { Prospective open label cohort; survival } \\
\text { compared with predicted survival based on } \mathrm{NIH} \\
\text { equation }\end{array}$ \\
\hline Sitbon ${ }^{20}$ & Oral bosentan & 139 & $0 / 0 / 139 / 0$ & & 97 & 91 & & & & 91 & 84 & & & $\begin{array}{l}\text { Prospective open label cohort; survival } \\
\text { compared with concurrent or historical } \\
\text { epoprostenol treated cohorts ( } n=346)\end{array}$ \\
\hline
\end{tabular}

several studies is a comparison of observed survival in a treated cohort of patients with idiopathic PAH with their expected survival which is based on haemodynamic severity of pulmonary hypertension and calculated from a reference equation derived from patients with idiopathic PAH in the National Institutes of Health (NIH) Registry.2 23 Since patients in the NIH Registry were managed at recognized US pulmonary hypertension centres between 1981 and 1985, other differences and advances in the quality of care-both recognised (such as more widespread current use of systemic anticoagulation) and unrecognised-may bias in favour of the survival of contemporary cohorts, independent of the treatment under study.

Despite the above limitations, most would accept that several of the new treatments do indeed increase survival of patients with idiopathic PAH. It is noteworthy that trials of new treatments for pulmonary hypertension have largely enrolled idiopathic PAH patients with the most advanced disease (WHO functional class III and IV). Thus, survival benefit with the newer treatments may not necessarily be seen in idiopathic PAH patients with earlier WHO class I and II functional status and will clearly be harder to demonstrate, given the longer natural history of disease in such patients. Furthermore, all trials have included patients on other treatments that may independently modify survival, including systemic anticoagulation. ${ }^{24}$ This approach of concomitant treatment with two or more agents addressing different pathobiological pathways is the future of pulmonary hypertension treatment and several formal combination treatment trials are in progress.

\section{FUTURE THERAPEUTIC DIRECTIONS IN PAH}

Unfortunately, the limitations in the studies described will probably be propagated in future studies. It would clearly be unethical to perform a placebo controlled trial of a new treatment for pulmonary hypertension with survival as an end point. Moreover, the increasing availability of effective oral treatment will make recruitment more difficult for future placebo controlled trials. Studies will increasingly compare the effects of new agents with those of established agents, as in the study by Sitbon et al in this issue which compared survival in bosentan treated and epoprostenol treated patients.

The focus of clinical trials of new PAH treatments is also broadening to include increasing numbers of patients with other types of pulmonary hypertension such as PAH secondary to connective tissue disease or congenital heart disease. However, large groups of patients with pulmonary hypertension remain unstudied and largely untreated, such as those with inoperable chronic thromboembolic pulmonary hypertension and pulmonary hypertension due to underlying cardiac or pulmonary disease.
Finally, given the difficulty in assessing a survival benefit, what other end points should we assess in future trials of new treatments for pulmonary hypertension? Quality of life is an important end point as pulmonary hypertension is associated with severe symptoms and functional limitation, and objective measurement tools are being developed. The symptoms, exercise limitation, and poor prognosis in pulmonary hypertension relate closely to the impairment of right ventricular function. Direct assessment of right ventricular size and function with new imaging approaches (such as three-dimensional echocardiography or MRI) and haemodynamic measurements (such as during exercise) will facilitate assessment of the severity of idiopathic PAH and quantify the decline over time or response to treatment. Moreover, new biological and genetic markers related to the pathobiology of pulmonary hypertension are currently being studied and may be useful parameters for diagnosis, assessment of severity, and guiding therapeutic decisions.

Patients with idiopathic PAH have clearly benefited from tremendous advances in the science and practice of pulmonary hypertension. However, many other patients with pulmonary hypertension have yet to benefit from the new treatments. We expect that treatments for pulmonary hypertension currently available and being developed will also lead to improvements in the quality of life, right ventricular function, and 
improved survival for patients with many other types of pulmonary hypertension.

Thorax 2005;60:981-983.

doi: $10.1136 /$ thx.2005.045674

\section{Authors' affiliations}

S Mehta, G J Shoemaker, Southwest Ontario Pulmonary Hypertension Clinic, Divisions of Respirology and Cardiology, Departments of Medicine, London Health Sciences Center, and The Centre for Critical Illness Research, Lawson Health Research Institute, University of Western Ontario, London, Ontario Canada

Correspondence to: Dr S Mehta, Division of Respirology, London Health Sciences Center South Street Hospital, London, Ontario, Canada N6A 4G5; sanjay.mehta@lhsc.on.ca

$S M$ has received consulting and speaking fees (Actelion, Encysive, Glaxo-BurroughsWellcome, Pfizer) and clinical investigator fees (Actelion, Encysive, Pfizer). GJS has received consulting and speaking fees (Actelion).

\section{REFERENCES}

1 Mendeloff EN, Meyers BF, Sundt TM, et al. Lung transplantation for pulmonary vascular disease. Ann Thorac Surg 2002;73:209-17.

2 Klepetko W, Mayer E, Sandoval J, et al. Interventional and surgical modalities of treatment for pulmonary arterial hypertension. J Am Coll Cardiol 2004;43:73-80S.

3 Doyle RL, McCrory D, Channick RN, et al. Surgical treatments/interventions for pulmonary arterial hypertension: ACCP evidence-based clinical practice guidelines. Chest 2004;126:63-71S
4 Pietra GG, Edwards WD, Kay JM, et al. Histopathology of primary pulmonary hypertension. A qualitative and quantitative study of pulmonary blood vessels from 58 patients in the National Heart, Lung, and Blood Institute, Primary Pulmonary Hypertension Registry. Circulation 1989;80:1 198-206.

5 Geggel RL, Carvalho AC, Hoyer LW, et al. von Willebrand factor abnormalities in primary pulmonary hypertension. Am Rev Respir Dis 1987; 135:294-9

6 Fuster V, Steele PM, Edwards WD, et al. Primary pulmonary hypertension: natural history and the importance of thrombosis. Circulation 1984:70:580-7.

7 Rich S, Kaufmann E, Levy PS. The effect of high doses of calcium-channel blockers on survival in primary pulmonary hypertension. N Engl J Med 1992;327:76-81.

8 Badesch DB, Abman SH, Ahearn GS, et al. Medical therapy for pulmonary arterial hypertension: ACCP evidence-based clinical practice guidelines. Chest 2004; 126:35-62S.

9 Barst RJ, Rubin $\sqcup$, Long WA, et al. A comparison of continuous intravenous epoprostenol (prostacyclin) with conventional therapy for primary pulmonary hypertension. The Primary Pulmonary Hypertension Study Group. N Engl J Med 1996;334:296-302.

10 Channick RN, Simonneau G, Sitbon O, et al. Effects of the dual endothelin-receptor antagonist bosentan in patients with pulmonary hypertension: a randomised placebo-controlled study. Lancet 2001;358:1119-23.

11 Rubin L, Badesch DB, Barst RJ, et al. Bosentan therapy for pulmonary arterial hypertension. N Engl J Med 2002;346:896-903.

12 Olschewski H, Simonneau G, Galie N, et al. Inhaled iloprost for severe pulmonary hypertension. N Engl J Med 2003;347:322-9.

13 Simonneau G, Barst RJ, Galie N, et al. Continuous subcutaneous infusion of treprostinil, a prostacyclin analogue, in patients with pulmonary arterial hypertension: a double-blind, randomized, placebo-controlled trial. Am J Respir Crit Care Med 2002; 165:800-4.
14 Robin ED. The kingdom of the near-dead. The shortened unnatural life history of primary pulmonary hypertension. Chest 1987;92:330-4.

15 Sitbon O, Humbert $M$, Jais $X$, et al. Long-term response to calcium channel blockers in idiopathic pulmonary arterial hypertension. Circulation 2005;111:3105-11.

16 McLaughlin VV, Shillington A, Rich S. Survival in primary pulmonary hypertension: the impact of epoprostenol therapy. Circulation 2003;106: 1477-82.

17 Sitbon O, Humbert $M$, Nunes $H$, et al. Long-term intravenous epoprostenol infusion in primary pulmonary hypertension: prognostic factors and survival. J Am Coll Cardiol 2003;40:780-8.

18 Kuhn KP, Byrne DW, Arbogast PG, et al. Outcome in 91 consecutive patients with pulmonary arterial hypertension receiving epoprostenol. Am J Respir Crit Care Med 2003;167:580-6.

19 Nagaya N, Uematsu M, Okano Y, et al. Effect of orally active prostacyclin analogue on survival of outpatients with primary pulmonary hypertension. J Am Coll Cardiol 1999.34:1188-92.

20 Sitbon O, McLaughlin VV, Badesch DB, et al. Survival in patients with class III idiopathic pulmonary arterial hypertension treated with first ine oral bosentan compared with an historical cohort of patients started on intravenous epoprostenol. Thorax 2005;60:1025-30.

21 McLaughlin VV, Sitbon O, Badesch DB, et al. Survival with first-line bosentan in patients with primary pulmonary hypertension. Eur Respir J 2005;25:244-9.

22 D'Alonzo GE, Barst RJ, Ayres SM, et al. Survival in patients with primary pulmonary hypertension. Results from a national prospective registry. Ann Intern Med 1991:115:343-9.

23 Sandoval J, Baverle O, Palomar A, et al. Survival in primary pulmonary hypertension. Validation of a prognostic equation. Circulation 1994:89: 1733-44.

24 Mehta S. Drug therapy for pulmonary arterial hypertension: what's on the menu today? Chest 2003; 124:2045-9.

\section{Pulmonary hypertension after splenectomy: a consequence of loss of the splenic filter or is there something more?}

\section{A J Peacock}

\section{The exact mechanism by which pulmonary hypertension develops} after splenectomy remains unclear

$\mathrm{P}$ ulmonary arterial hypertension is a syndrome - not a disease — and has a number of causes. ${ }^{1}$ Included in these causes are a wide range of pathoaetiologies such as HIV infection, portopulmonary hypertension, intracardiac shunt, chronic thromboembolic disease, hypoxic lung disease, connective tissue disease, idiopathic pulmonary hypertension, and familial pulmonary hypertension associated with mutation of the BMPR2 gene.

In this issue of Thorax Jaïs et $a l^{2}$ have examined the clinical background of 257 patients referred to their centre for treatment of chronic thromboembolic pulmonary hypertension (CTEPH). They found that $8.6 \%$ of the patients had a history of splenectomy compared with $2.5 \%$ of patients with idiopathic pulmonary hypertension (IPH) and $0.4 \%$ in the general population. They concluded that splenectomy alone had caused thromboembolism and hence the pulmonary hypertension in these patients. But is this true?

Chronic thromboembolic disease has been defined as "pulmonary hypertension caused by the absence of thrombus resolution after acute pulmonary embolism which has resulted in sustained obstruction of the pulmonary circulation". This view is probably outdated because in 50\% of cases there is no definite history of venous thrombosis and it is likely that many cases are a consequence of in situ thrombosis. $^{3}$ Bonderman et $a l^{4}$ have recently looked at the medical conditions that increased the risk of CTEPH in 109 consecutive patients and found that splenectomy increased the relative risk of this condition by a factor of 13 .

The findings of Jaiis et $a l^{2}$ and Bonderman et $a l^{4}$ are not new-for example, Hoeper et al found an $11.5 \%$ incidence of splenectomy in 61 patients with pulmonary hypertension. In the papers by Jaïs et $a l^{2}$ and Hoeper $e t a l^{5}$ it appears that splenectomy increases the risk of both IPH and CTEPH. For example, Jaïs et al found an incidence of splenectomy of $2.5 \%$ even in the patients with IPH. Interestingly, of the $22 / 257$ with CTEPH who had had splenectomy, only eight were suitable for treatment by the standard operation of thromboendarterectomy, which suggests that they had distal disease. This raises the issue of the continuity between CTEPH, the thrombotic variant of IPH, and small vessel IPH 
without thrombosis. It may well be that the primary problem is not simply one of increased coagulability due to loss of the splenic filter but one of abnormal endothelial surface resulting in in situ thrombosis or another factor. Certainly, in IPH the survival can be doubled simply by the use of warfarin and, in these cases, there is no history of venous thromboembolism. ${ }^{6}$

The simplest explanation for the finding of Jaïs $e t a l^{2}$ and of the other authors who have studied this problem is that, following splenectomy, there is both thrombocytosis and also increased numbers of damaged circulating red cells which will activate these platelets leading to in situ thrombosis. There is some evidence for this view. For example, we know that in the haemolytic disorders where there is an excess of haemolysed red cells there is also excess coagulability as shown by the increased capacity of the red cells to generate thrombin. ${ }^{7}$ This phenomenon was discovered in patients with thalassaemia intermedia, but there are a number of reports of CTEPH in patients with other haemolytic disorders-for example, pyruvate kinase deficiency, ${ }^{8}$ congenital spherocytosis, ${ }^{9}$ and stomatocytosis. ${ }^{10}$ The complicating factor is that, for many of these conditions, splenectomy is a treatment and therefore it is difficult to differentiate between hypercoagulability caused by the splenectomy per se and hypercoagulability caused by the underlying haemolytic disease. Furthermore, we do not know whether it is simply the prothrombotic component of the disease that is important or whether there is some other factor which could lead to pulmonary hypertension separately from pulmonary vascular thrombosis. For example, haemoglobin released from haemolysed red cells present in the plasma would scavenge nitric oxide which is an important pulmonary vasodilator.

Certainly, when splenectomy is performed to treat a haemolytic disorder, the combination of the haemolytic disorder and the splenectomy seem to increase the likelihood of pulmonary thromboembolism further, due in part to the excess thrombin generated by the abnormal red cells. Cappellini et $a l^{7}$ studied a large group of adults with both thalassaemia intermedia and thalassaemia major for up to 10 years and found a high prevalence of thromboembolic events, particularly in the splenectomised patients, which was associated with an enhanced capacity to generate thrombin by the thalassaemic red cells. This enhanced capacity was not seen in patients who had a splenectomy for other reasons-that is, it was not a function of the splenectomy per se. It is likely, however, that the splenectomy exacerbated the situation by the reduced clearance of abnormal red cells. This would suggest that, in many cases, it is not splenectomy alone which causes the problem but splenectomy in the face of an underlying haemolytic disorder. There is some evidence for this view. Boxer et $a l^{11}$ studied 318 otherwise fit patients who had been treated by splenectomy and found that $75 \%$ had increased platelet levels immediately following the operation but there were no increased incidence of venous thromboembolism. This may be because the thrombocytosis normally diminishes following splenectomy and it is only if it persists that the pulmonary hypertension develops. For example, Rostagno et $a l^{12}$ described a patient who suffered CTEPH associated with long standing thrombocytosis but, when the thrombocytosis was treated, there was improvement in both the clinical state and in the pulmonary haemodynamics. Marvin and Spellberg ${ }^{13}$ described another patient who had thrombocytosis and developed pulmonary hypertension and right heart failure following splenectomy, but treatment of the thrombocytosis with hydroxyurea improved both vascular and cardiac function.

The finding that splenectomy alone seems to be benign, but that splenectomy in the face of an underlying haemolytic disorder results in a high incidence of pulmonary hypertension (for example, Aessopos et al ${ }^{14}$ found that $59 \%$ of patients with thalassaemia intermedia who had had splenectomy developed thromboembolic pulmonary hypertension) suggests that it is a combination of the two factors-namely, an abnormality of red cells (and possibly platelets) and splenectomy-that leads to pulmonary hypertension and in situ thrombosis. However, there is other evidence that splenectomy can cause pulmonary hypertension in patients who do not have haemolytic disorders. For example, Elstein et a ${ }^{15}$ showed that, in 134 patients with Gaucher's disease, 7\% had pulmonary hypertension detected by echocardiography. It is interesting that most of these had been treated by splenectomy. In the paper by Jaïs et al $^{2}$ in this issue of Thorax only four of the 22 patients who developed CTEPH after splenectomy had a haemolytic disorder, and in most of the others the spleen had been removed for trauma.

What is of great interest is the long time interval (range 2-35 years) between the splenectomy in the patients studied by Jaïs et $a l^{2}$ and the development of thromboembolic pulmonary hypertension. This suggests either that the development of pulmonary hypertension is a very slow process or that some additional factor developed which resulted in a prothrombotic state, perhaps a change in endothelial function or a change in red cell characteristics.

From the above it is clear that splenectomy is a risk for thromboembolic hypertension, particularly in patients who have had splenectomy for a haemolytic disorder. It is also clear that clinicians should watch these patients carefully and consider whether long term anticoagulation would be appropriate. We should also keep an eye on patients who have had splenectomy for other reasons because they do not appear to be immune from the development of pulmonary hypertension. The exact mechanism by which pulmonary hypertension develops after splenectomy, even in patients with underlying haemolytic disorders, remains unclear but provides a fascinating model for future research.

Thorax 2005;60:983-984

doi: $10.1136 /$ thx. $200 \times .043216$

Correspondence to: Professor A J Peacock, Scottish Pulmonary Vascular Unit, Western Infirmary, Glasgow G11 6NT, UK; apeacock@ udcf.gla.ac.uk

\section{REFERENCES}

1 Simonneau G, Galie N, Rubin U, et al. Clinical classification of pulmonary hypertension. J Am Coll Cardiol 2004:43:5-12S

2 Jaïs X, loos V, Jardim C, et al. Splenectomy and chronic thromboembolic pulmonary hypertension. Thorax 2005;60:1031-34.

3 Egermayer $P$, Peacock AJ. Is pulmonary embolism a common cause of pulmonary hypertension? Limitations of the embolic hypothesis. Eur Respir J 2000;15:440-8.

4 Bonderman D, Jakowitsch J, Aldbrecht C, et al. Medical conditions increasing the risk of chronic thromboembolic pulmonary hypertension Thromb Haemost 2005;93:512-6.

5 Hoeper MM, Neidermeyer J, Hoffmeyer F, et al Pulmonary hypertension after splenectomy? Ann Intern Med 1999:130:506-9.

6 Rich S, Kauffmann E, Levy PS. The effect of high dose calcium channel blockers on survival in primary pulmonary hypertension. N Engl J Med 1992;327:76-81

7 Cappellini MD, Robbiolo L, Bottasso BM, et al. Venous thromboembolism and hypercoaguability in splenectomised patients with thalassaemia intermedia. Br J Haematol 2000; 1 1 1:467-73.

8 Chou R, Deloughery TG. Recurrent thromboembolic disease following splenectomy for pyruvate kinase deficiency. Am J Haematol $2001 ; 67: 197-9$

9 Jardine DL, Laing AD. Delayed pulmonary hypertension following splenectomy for congenital spherocytosis. Int Med J 2004;34:214-6.

10 Murali B, Drain A, Seller D, et al. Pulmonary thromboendarterectomy in a case of hereditary stomatocytosis. Br J Anaesth 2003;91:739-41.

11 Boxer MA, Braun J, Ellman L. Thromboembolic risk of postsplenectomy thrombocytosis. Arch Surg 1978; 113:808-9.

12 Rostagno C, Prisco D, Abbate R, et al. Pulmonary hypertension associated with long standing thrombocytosis. Chest 1991;99:1303-5.

13 Marvin KS, Spellberg RD. Pulmonary hypertension secondary to thrombocytosis in a patient with myeloid metaplasia. Chest 1993;103:642-4.

14 Aessopos A, Farmakis D, Karagiorga M, et al. Cardiac involvement in thalassemia intermedia: a multicenter study. Blood 2001;97:3411-6.

15 Elstein D, Klutstein MW, Lahad A, et al. Echocardiographic assessment of pulmonary hypertension in Gaucher's disease. Lancet 1998;351:1544-6. 


\section{Paediatric respiratory mortality: past triumphs, future challenges}

\section{G Russell}

\section{Radical new ideas are needed to ensure that deaths from respiratory diseases in children continue to fall}

$\mathrm{T}$ he invitation to comment on a paper that reports changes which occurred during a period that coincided, within a year or two, with my career as a consultant paediatrician presents me with an irresistible temptation to reminisce. At medical school in the late 1950s I learned that pneumonia, one time captain of the men of death, had responded dramatically first to sulphonamides and then to penicillin, but that some deaths were still "inevitable" - a phrase much used at that time to excuse our inability to manage conditions that we did not fully understand. Asthma was common in children but was considered to be an unusual cause of death, although it was responsible for the first death I encountered as a paediatric senior house officer. In the minds of my teachers asthma was readily distinguished from bronchitis and, to this day, I can replicate a table listing the differences between asthma and wheezy bronchitis, most of which has-to my surprise-turned out to be accurate. ${ }^{1}$ In those far off days most children with cystic fibrosis (CF) died in the pre-school years; Pseudomonas species were not the problem they are now and most children died while still colonised with Staphylococcus aureus or Haemophilus influenzae. Bronchiolitis was considered to be rather an esoteric diagnosis for which there was no diagnostic test - it would be a few years before its association with the respiratory syncytial virus (RSV) was appreciated. $^{2}$ It was thought safer to diagnose pneumonia if crackles were prominent and to treat the child with antibiotics, while those with predominant wheeze were labelled "bronchitis" and given ephedrine.

In the mid 1960s I extracted data from the Registrar General's annual reports when, as a junior, I presented a fatal case of staphylococcal bronchopneumonia to a clinicopathological conference. I was surprised to find not only that there was still considerable childhood mortality from pneumonia but also that, following the rapid decline already mentioned, it had been more or less stable for the previous decade. In my presentation I attributed this to the emergence of penicillin resistant $S$ aureus, an organism that had become ubiquitous despite the widespread presence of gimlet-eyed matrons who, some politicians would have us believe, have the power to stop the more recently emerged methicillin resistant $S$ aureus in its tracks.

By 1968, the first year of the study by Panickar et $a l^{3}$ reported in this issue of Thorax, major changes were afoot. Coincident with-but not necessarily due to-the development of new antibiotics, pneumonia mortality had begun to fall, and when I prepared a figure to illustrate a chapter in a textbook ${ }^{4}$ it was clear that mortality from pneumonia was back on its downward track, on which it has remained despite the emergence of respiratory pathogens of vastly greater virulence and antibiotic resistance than anything we had to deal with 40 years ago. Some children with CF were now entering secondary school, although their survival there was usually brief. Overnight incarceration in mist tents was part of the burden borne by patients with CF; in 1968 I was trying to raise money to purchase tents and was still doing so a few years later when Archie Norman demonstrated their inefficacy. ${ }^{5}$ Antibiotic treatment had improved but nutritional management was woefully inadequate; looking back, it is hard to believe that the era of the Allan diet ${ }^{6}$ had not even arrived, far less departed. However, by 1968 we were becoming more secure in the diagnosis of bronchiolitis, although we had to rely on rising antibody titres to demonstrate the presence of RSV; the immunofluorescent technique for the rapid diagnosis of RSV infection was described in $1968^{7}$ but would not be in widespread use for several years. In the absence of an organised system of paediatric intensive care units, the availability of artificial ventilation depended on the interest and enthusiasm of local anaesthetists and paediatricians. Asthma was also a continuing problem; salbutamol was announced that year ${ }^{8}$ but was not yet available for clinical use, and inhaled corticosteroids were a few years over the horizon. ${ }^{9}$ The study by Panickar et al $^{3}$ therefore covers a period during which there were major developments in what we now regard as basic aspects of the management of respiratory tract diseases.

\section{RESPIRATORY DISEASES STUDIED Pneumonia}

The improving mortality from pneumonia reflects many medical advances other than new antibiotics. Panickar et al emphasise the importance of immunisations, to which I would add the developments in the organisation and delivery of paediatric intensive care that have occurred in recent years. Nevertheless, there are no grounds for complacency. Children are still dying from pneumonia, and although we have useful guidelines for the management of community acquired pneumonia ${ }^{10}$ - albeit derived from a somewhat scanty evidence base - the management and, perhaps more importantly, the prevention of nosocomial pneumonia remains problematical. ${ }^{11}$

\section{Asthma}

However, pneumonia is not the only important cause of respiratory mortality in children. Although fewer than 5\% of asthma deaths occur in childhood, ${ }^{12}$ asthma is an eminently treatable condition and our objective should be to reduce this figure to zero. Most asthmatic children who reach hospital alive will survive, the majority of deaths occurring outside hospital. ${ }^{13}$ Management in the community is therefore of prime importance. Although there is controversy about the role of written management plans in improving asthma care, ${ }^{14}$ there is no doubt that comprehensive asthma management programmes are effective in reducing asthma morbidity and hospital admissions. ${ }^{15}$ The problem is not that we don't know what to do, but that the very patients who need to be included in such programmes-and in whom much of the childhood asthma morbidity and mortality occurs-are hard to reach because a combination of socioeconomic deprivation, ${ }^{16}$ family problems, and psychological factors ${ }^{17}$ leads to failure to recognise the severity of an attack and failure to seek medical help in time. ${ }^{18}$

\section{Cystic fibrosis}

It is already well known that the mortality from CF has fallen to the extent that it is no longer an important cause of childhood death. ${ }^{19}$ This improvement has, however, been bought at a considerable price in terms of parental stress ${ }^{20}$ and family disruption ${ }^{21}$ - stress that was described at a recent meeting as "the daily grind." 22 Moreover, socioeconomic deprivation has a substantial adverse impact on the outcome for patients with $\mathrm{CF}^{23}$ as evidenced for instance by the 
poorer clinical progress made by CF children of single parents. ${ }^{24}$

Panickar et al found that, for most respiratory conditions, mortality is still higher in boys than in girls. However, the reverse is true in CF. Girls, who are so often model patients during childhood and comply conscientiously with the rigours of treatment, commonly deteriorate during adolescence, creating a gender gap in mortality that was demonstrated clearly in data from the UK CF Survey. ${ }^{25}$ An examination of the large database maintained by the US CF Foundation showed that, after adjustment for other risk factors, female sex was a significant risk factor for death in patients $<21$ years of age, with a relative risk compared to males of $1.6 .^{26}$ Although the added disadvantage suffered by adolescent girls with CF is widely recognised, it has never been adequately explained. Studies have demonstrated differences between the sexes in energy intake $e^{27}$ and resting energy expenditure, ${ }^{28}$ in everyday activity levels, ${ }^{29}$ and in some psychological traits, ${ }^{30}{ }^{31}$ but none of these offers a convincing explanation for the large excess in female mortality.

In addition to applying the medical advances that must sooner or later flow from our increased understanding of the molecular biology of $\mathrm{CF}$, future challenges include narrowing the gender gap in mortality, improved delivery of care to economically disadvantaged families, and reduction of the psychosocial impact of the CF child on other family members.

\section{Acute viral bronchiolitis}

The last major cause of paediatric respiratory death discussed by Panickar et al is acute viral bronchiolitis. The antiviral drug ribavirin, given as a small particle aerosol, has failed to live up to early expectations ${ }^{32}$ and is unlikely to have had much influence on mortality. The use of palivizumab, an effective monoclonal antibody directed against RSV, is reserved for high risk cases and the extent of its use varies widely. Its introduction was too recent to have affected mortality in all but the most recent years of the study, and the dramatic falls in mortality must therefore be attributed to improvements in general paediatric care together with improved access to paediatric intensive care.

\section{IMPLICATIONS OF STUDY FINDINGS}

So what are the lessons to be learned from this report on childhood mortality? Clearly, paediatric respirologists are getting results at least as satisfactory as those of their colleagues in other paediatric specialties. Deaths are at an all-time low, and for this we can allow ourselves a moment's satisfaction. However, much remains to be done. One obvious need is for well designed clinical trials in almost every aspect of paediatric respirology, to allow us to fine-hone our management and to discard useless treatments. In particular, although the excellent results obtained in $\mathrm{CF}$ in the absence of a satisfactory evidence base testify to the value of clinical experience and common sense in directing patient care, our use of ever more expensive and complex treatments must in future be more rationally based.

However, one challenge that will tax our ingenuity and for which no obvious solution is in sight is the delivery of health education and medical care to families from socially disadvantaged backgrounds. Many governments have pledged to reduce social inequalities in health, but the gap persists obstinately. ${ }^{33}$ These differences are seen throughout the world, between as well as within nations, ${ }^{34}$ and a solution to the problem has so far proved elusive. As we have seen, paediatric respirology is by no means immune to these problems; there will be little benefit from screening for $\mathrm{CF}$ or improving asthma management plans if our attempts to deliver appropriate care are frustrated by socioeconomic and psychological barriers. Paediatricians are accustomed to working in multidisciplinary teams, but perhaps it is time to reconsider the composition of such teams which, in the past, have tended to be diseasespecific. Should we be making better use of the more generic facilities of the school health service, ${ }^{35}$ the social work department, ${ }^{36}$ or the clinical psychology department? Whatever the ultimate solution, it is clear that current practice is inadequate and that radical new ideas are needed.

Thorax 2005;60:985-986.

doi: $10.1136 /$ thx. 2005.050773

Correspondence to: Professor G Russell, Department of Child Health, University of Aberdeen, Aberdeen AB9 2ZD, UK; libra@ifb. co.uk

\section{REFERENCES}

1 Wassall HJ, Devenny AM, Daud Khan S, et al. A comparison of virus-associated and multi-trigger wheeze in school children. J Asthma 2005;42:737-44.

2 Chanock RM, Kim HW, Vargosko AJ, et al. Respiratory syncytial virus. I. Virus recovery and other observations during 1960 outbreak of bronchiolitis, pneumonia, and minor respiratory diseases in children. JAMA 1961;176:647-53.

3 Panickar JR, Dodd SR, Smyth RL, et al. Trends in deaths from respiratory illness in children in England and Wales from 1968 to 2000 . Thorax 2005;60: 1035-38.

4 Forfar JO, Arneil GC. Textbook of paediatrics. 2nd ed. Edinburgh: Churchill Livingstone, 1978:16.

5 Norman AP. Nocturnal mist therapy in cystic fibrosis. Practitioner 1971;206:786-90.

6 Allan JD, Milner J, Moss D. Therapeutic use of an artificial diet. Lancet 1970;i:785-6.

7 McQuillin J, Gardner PS. Rapid diagnosis of respiratory syncytial virus infection by immunofluorescent antibody techniques. BMJ 1968;1:602-5.

8 Hartley D, Jack D, Lunts LHC, et al. New class of selective stimulators of $\beta$-adrenergic receptor. Nature 1968;219:861-2.
9 Brown HM, Storey G, George WH. Beclomethasone dipropionate: a new steroid aerosol for the treatment of allergic asthma. BMJ 1972;1:585-90.

10 British Thoracic Society. British Thoracic Society guidelines for the management of community acquired pneumonia in childhood. Thorax 2002;57(Suppl I):i1-24.

11 Zar HJ, Cotton MF. Nosocomial pneumonia in pediatric patients: practical problems and rational solutions. Paediatr Drugs 2002;4:73-83.

12 Sturdy PM, Victor CR, Anderson HR, et al. Psychological, social and health behaviour risk factors for deaths certified as asthma: a national case-control study. Thorax 2002;57:1034-9.

13 Fletcher HJ, Ibrahim SA, Speight N. Survey of asthma deaths in the northern region: 19701985. Arch Dis Child 1990;65:163-7.

14 Toelle BG, Ram FS. Written individualised management plans for asthma in children and adults. Cochrane Database Syst Rev, 2004:CD002171.

15 Mitchell EA, Didsbury PB, Kruithof N et al. A randomized controlled trial of an asthma clinical pathway for children in general practice. Acta Paediatr 2005;94:226-33.

16 Castro M, Schechtman KB, Halstead J, et al. Risk factors for asthma morbidity and mortality in a large metropolitan city. J Asthma 2001 ;38:625-35.

17 Bloomberg GR, Chen E. The relationship of psychologic stress with childhood asthma. Immunol Allergy Clin North Am 2005;25:83-105.

18 Fletcher HJ, Ibrahim SA, Speight N. Survey of asthma deaths in the northern region: 19701985. Arch Dis Child 1990;65:163-7.

19 Dodge JA, Lewis PA. Cystic fibrosis is no longer an important cause of childhood death in the UK. Arch Dis Child 2005;90:547.

20 Burton L. Cystic fibrosis: a challenge to family strength. Health Visit 1973;46:186-9.

21 Begleiter ML, Burry VF, Harris DJ. Prevalence of divorce among parents of children with cystic fibrosis and other chronic diseases. Soc Biol 1976;23:260-4.

22 Hunter V. The daily grind and how to stay sane as a mother of two children with cystic fibrosis. $J R$ Soc Med 2003:96(Suppl 43):51-6.

23 O'Connor GT, Quinton HB, Kneeland T, et al. Median household income and mortality rate in cystic fibrosis. Pediatrics 2003; 111 :e333-9.

24 Macpherson C, Redmond AO, Leavy A, et al. A review of cystic fibrosis children born to single mothers. Acta Paediatr 1998;87:397-400.

25 Dodge JA, Morison S, Lewis PA, et al. Incidence, population, and survival of cystic fibrosis in the UK, 1968-95. UK Cystic Fibrosis Survey Management Committee. Arch Dis Child 1997;77:493-6.

26 Rosenfeld M, Davis R, FitzSimmons S, et al. Gender gap in cystic fibrosis mortality. Am J Epidemiol 1997;145:794-803.

27 Collins CE, O'Loughlin EV, Henry R. Discrepancies between males and females with cystic fibrosis in dietary intake and pancreatic enzyme use. J Pediatr Gastroenterol Nutr 1998:26:258-62.

28 Allen JR, McCauley JC, Selby AM, et al. Differences in resting energy expenditure between male and female children with cystic fibrosis. $J$ Pediatr 2003;142:15-9.

29 Selvadurai HC, Blimkie CJ, Cooper PJ, et al. Gender differences in habitual activity in children with cystic fibrosis. Arch Dis Child 2004;89:928-33.

30 Willis E, Miller R, Wyn J. Gendered embodiment and survival for young people with cystic fibrosis. Soc Sci Med 2001;53:1 163-74.

31 Gee L, Abbott J, Conway SP, et al. Quality of life in cystic fibrosis: the impact of gender, general health perceptions and disease severity. J Cyst Fibros 2003;2:206-13.

32 Kimpen JL. Management of respiratory syncytial virus infection. Curr Opin Infect Dis $2001 ; 14: 323-8$.

33 Corbin T. Mortality in children aged under 8. Health Stat Q 2004:30-7.

34 Anon. The WHO European report confirms links between socioeconomic development and health. Eur Surveill 2002;7:143-4.

35 Tinkelman D, Schwartz A. School-based asthma disease management. J Asthma 2004;41:455-62.

36 Anon. New inner-city asthma interventions put social workers in the driver's seat. Dis Manag Advis 2003;9:111-5. 


\section{Thorax Annual Report October 2004 - September 2005}

\section{J A Wedzicha, E C Howard, S L Johnston, D M Mitchell}

W have now completed three years of our editorship and this pastyear has been the busiest, but also very rewarding. We are pleased to let you know that, over the past year, Thorax has continued to flourish as a successful high quality respiratory journal. ${ }^{1-3}$

One of the highlights of the year has been that our impact factor has risen from 4.188 in 2003 to 5.040 for 2004 (table 1). ${ }^{45}$ The impact factor that was published in 2005 reflects the number of citations in 2004 divided by the number of original papers and reviews published in Thorax in 2002 and 2003. Thorax is the second highest ranked respiratory journal in terms of impact factor, behind the American Journal of Respiratory and Critical Care Medicine. The number of articles (excluding editorials and letters) published in Thorax has remained relatively constant, with 183 articles in 2001, 210 in 2002, 198 in 2003, and 195 in 2004. Thus, the improvement in the impact factor has reflected the increased number of citations in the medical literature to Thorax papers and this is a result of the high quality papers that you have sent to the journal and the rigour of our peer review process.

Over the past year the number of submissions to the journal was at 1503, of which 913 were full original papers and the remainder were editorials, reviews, case reports, Images in Thorax, and letters. Table 2 shows the geographical spread of submissions to Thorax over the past 6 years. The numbers of papers coming from the UK, Europe (excluding UK), Japan and Australasia have remained steady while, over the past year, we have observed a welcome increase in submissions from North America, Canada, and Asia. Our acceptance rate for original research papers now stands at $15 \%$ and, for case reports and "Images in Thorax", our acceptance rate is only $6.25 \%$.

We would like to thank all the many reviewers who have given up their valuable time to assess papers for Thorax and contributed to the success of the journal. ${ }^{7}$ A list of all the reviewers for the journal during the past 12 months is published after this editorial. During the year, 1402 reviews on Thorax papers were returned by 784 reviewers. Table 3 shows the origin of reviewers by country: $40.4 \%$ were from the UK, $23.3 \%$ from other areas of Europe excluding the UK, 23.9\% from the USA and Canada, and 8.7\% from Australasia. We would particularly like to encourage new reviewers to come forward from Asia, Japan, South America, and Africa where the number of Thorax reviewers at present is particularly low. Please register on the Thorax submission website or contact the editors directly. We would particularly like to thank our two statistical reviewers who, between them, have reviewed carefully every potentially acceptable manuscript with statistical data during the year, which amounts to about 350 papers and revisions. Rigorous statistical review in addition to peer review has considerably improved the quality of the final manuscript published in the journal.

This year we have also provided some guidance on the requirements for publication of genetic association studies in Thorax. We noticed that many studies submitted have been underpowered or poorly designed, and we have published an editorial containing guidance on some of the key issues that need to be addressed when assessing the validity of genetic association studies. Already the standard of genetics papers in the journal has improved, and we urge our authors to study these requirements. ${ }^{8}$

We have continued to develop our educational features, including Airwaves at the front of the journal, Lung Alerts

Table 1 Journal impact factors for 2004: respiratory journals

\begin{tabular}{ll}
\hline Journal & $\begin{array}{l}\text { Impact } \\
\text { factor }\end{array}$ \\
\hline $\begin{array}{l}\text { American Journal of Respiratory } \\
\text { and Critical Care Medicine }\end{array}$ & 8.123 \\
$\begin{array}{l}\text { Thorax } \\
\text { American Journal of Respiratory } \\
\text { Cell and Molecular Biology }\end{array}$ & 5.040 \\
$\begin{array}{l}\text { American Journal of Physiolog } \\
\text { - Lung Cellular and Molecular }\end{array}$ & 4.051 \\
$\begin{array}{l}\text { Pathology } \\
\text { Respiratory Research }\end{array}$ & 4.028 \\
$\begin{array}{l}\text { Journal of Thoracic and } \\
\text { Cardiovascular Surgery } \\
\text { Chest }\end{array}$ & 3.263 \\
$\begin{array}{l}\text { European Respiratory Journal } \\
\text { Journal of Heart and Lung }\end{array}$ & 3.118 \\
$\begin{array}{l}\text { Transplantation } \\
\text { Respiratory Medicine }\end{array}$ & 2.096 \\
\hline
\end{tabular}

(short summaries of papers published in general and non-respiratory journals and serviced by our younger readers), ${ }^{10}$ and "Images in Thorax". ${ }^{6}$ This series has proved very popular and educational and we have received 111 high quality submissions for the Images series over the year. The series has been available free of charge since November 2003 in a collection on the Thorax website (http://thorax.bmjjournals.com/cgi/collection/images). We also published a report on the British Thoracic Society Winter meeting held in London in December 2004. ${ }^{11}$ This year we have completed review series on aspects of $\alpha_{1^{-}}$ antitrypsin deficiency ${ }^{12}{ }^{13}$ and sleep disordered breathing, ${ }^{14-17}$ and published a number of interesting occasional reviews on topics such as home oxygen for children, ${ }^{18}$ asbestos and lung cancer, ${ }^{19}$ pulmonary hypertension in chronic obstructive pulmonary disease (COPD), ${ }^{20}$ and epithelial growth factor. ${ }^{21}$ Finally, for our researchers we published a useful editorial about obtaining research grant funding. ${ }^{22}$

The Thorax website (www.thoraxjnl. com) has proved very popular and our 10 most frequently read articles online over the past year had a total of 129004 accesses either as full text, PDF versions, or abstracts. ${ }^{23-32}$ This is a rise of $23 \%$ in the accesses to the 10 most frequently read papers online compared with the previous year at 104602 .

Another important innovation in the journal this year has been the Online First service where original articles are posted on the Thorax website soon after acceptance, before technical editing and before publishing in the print version. Although our publication lag for the print journal is still very short ( 3 months), authors of research papers want their articles cited as soon as possible after acceptance so that their results can influence further research and findings can be incorporated swiftly into clinical practice to the benefit of respiratory patients all over the world..$^{33}$

Correspondence is an important part of Thorax and reflects the activity and interest in the journal. The number of letters to the editor submitted has increased from 99 last year to 109 this year; these consist of letters in response to published articles, research letters that are peer reviewed, and letters about specific clinical cases. There is also the facility to respond online to a published article by " $\mathrm{e}$ " letter, which is a useful tool for ensuring continued dialogue around papers published in Thorax. In view of the importance of letters in Thorax, we have recently appointed a specific letters editor whose remit is to coordinate all the correspondence in the journal and on the website.

Thorax editorials have been popular with our readers and the journal regards them as important educational content. Over the past year we published 52 editorials 
Table 2 Geographical distribution of submissions

\begin{tabular}{lrrrrrrr}
\hline Country & $\mathbf{2 0 0 0}$ & $\mathbf{2 0 0 1}$ & $\mathbf{2 0 0 2}$ & $\mathbf{2 0 0 3}$ & $\mathbf{2 0 0 4}$ & $\mathbf{2 0 0 5}$ & $\begin{array}{l}\text { \% of 2005 } \\
\text { submissions }\end{array}$ \\
\hline UK & 348 & 323 & 325 & 378 & 398 & 373 & 24.8 \\
Europe & 310 & 386 & 329 & 437 & 527 & 525 & 34.9 \\
(excluding UK) & & & & & & & \\
USA \& Canada & 87 & 68 & 74 & 126 & 146 & 187 & 12.4 \\
Japan & 56 & 69 & 74 & 99 & 107 & 100 & 6.7 \\
Australasia & 60 & 57 & 45 & 67 & 86 & 75 & 5.0 \\
Asia & 39 & 26 & 41 & 85 & 125 & 165 & 11.0 \\
South America & 5 & 7 & 6 & 21 & 23 & 25 & 1.7 \\
Africa & 4 & 5 & 1 & 6 & 11 & 18 & 1.2 \\
Middle East & 13 & 24 & 21 & 21 & 26 & 35 & 2.3 \\
\hline
\end{tabular}

and we would particularly like to thank all the authors who have agreed to write these-often at short notice. Fortunately, very few of you have turned down a request to write an editorial for Thorax.

We would like to thank all the Associate Editors who have provided expert help in selecting the best papers for publication and to the Lung Alert, Letters, and "Images in Thorax" editors for their hard work in making sure these features are of high quality and keeping to our tight publication deadlines. We are also grateful to our International Advisory Board for their support of the journal. During the year we held two meetings: one in November 2004 in London with all the Editors and Associate Editors and another with the Thorax Advisory Board at the American Thoracic Society (ATS) meeting in San Diego, USA in May 2005. Above all, we would like to thank all our authors who have sent us such high quality papers for review in the journal-please continue to send us your very best papers.

There are a number of respiratory journals now available and, as editors, we have all faced various complex issues and often difficult decisions regarding papers and particularly issues around publication ethics. In Thorax we have felt for some time that joint meetings of the editors and journal staff of the various respiratory journals would be very beneficial and supportive to us all. Thus, we were delighted when the other editors were enthusiastic about this idea and the first meeting was held at the ATS in May 2005, with a follow up meeting at the ERS (European Respiratory Society) in September 2005. We covered much ground with lively discussion around issues of mutual interest, got to know each other, and are developing our terms of reference for further meetings.

Andrea Horgan, the Managing Editor of Thorax, Ed Howard, the Development Editor, and Julia Cresswell have performed a superb job in running the journal and we are very grateful to them for all the support and advice they have provided us over the year. We would like to thank Liz Stockman, our Technical Editor, for preparing the monthly issues always to the highest standard and for chasing us so keenly to meet all the publication deadlines. Finally, we would like to thank Ed Neville, Sheila Edwards, and the BTS for their support of Thorax over the year.

As you can see from this report, it has been an exceptionally full and very successful year for the journal with a number of interesting developments. The high submission rates over the years 2004 and 2005 will ensure that we will be able to publish high quality papers in the coming year and build on the success achieved with Thorax. We are also interested to hear directly from our readers about any suggestions for improving the journal or its website. To this end, we would like to wish all our Thorax readers a very Happy Christmas and a productive and successful New Year.

Thorax 2005;60:987-989.

\section{Authors' affiliations}

J A Wedzicha, E C Howard, S L Johnston,

D M Mitchell, Thorax Editorial Office, BMA House, London, UK

Correspondence to: Professor J A Wedzicha, Thorax Editorial Office, BMJ Journals, BMA House, Tavistock Square, London WC1H 9JR, UK; j.a.wedzicha@medsch.ucl.ac.uk

\section{REFERENCES}

1 Wedzicha JA, Johnston SL, Mitchell DM. New Year, new editors. Thorax 2003:58:1-2.

2 Wedzicha JA, Johnston SL, Mitchell DM. Annual Report 2003. Thorax 2003;58:1015-7.

3 Wedzicha JA, Johnston SL, Mitchell DM. Annual Report 2003. Thorax 2004;59:1012-5.

4 Wedzicha JA, Johnston SL, Mitchell DM. Journal impact factors for 2003: Thorax increases. Thorax 2004;59:736

5 Wedzicha JA, Johnston SL, Mitchell DM. Journal impact factors for 2003: another rise for Thorax. Thorax 2005;60:712.

6 FitzGerald JM, Müller N, Hogg J. Images in Thorax. Thorax 2003;58:915.

7 Wedzicha JA, Johnston SL, Mitchell DM. Thank you to all Thorax reviewers. Thorax 2004;59:6-7.

8 Wedzicha JA, Hall IP. Publishing genetic association studies in Thorax. Thorax 2005:60:357.

9 Hall IP, Blakey JD. Genetic association studies in Thorax. Thorax 2005;60:357-9.

10 Wedzicha JA, Bhowmik A, Seemungal T. Call for Lung Alerts. Thorax 2003;58:193. doi: $10.1136 /$ thx. 2005.054577
Table 3 Country of origin of reviewers

\begin{tabular}{lrr}
\hline Country & \multicolumn{1}{l}{ No } \\
\hline UK & 317 & 40.4 \\
Europe (excluding UK) & 183 & 23.3 \\
USA \& Canada & 187 & 23.9 \\
Japan & 4 & 0.5 \\
Australasia & 68 & 8.7 \\
Asia & 10 & 1.3 \\
South America & 5 & 0.6 \\
Africa & 5 & 0.6 \\
Middle East & 5 & 0.6 \\
Total & 784 & 100 \\
\hline & &
\end{tabular}

11 Powrie DJ, Hurst JR. Breathing new life into respiratory medicine? Report of the 2004 BTS Winter Meeting. Thorax 2005;60:183-6.

12 Sandhaus RA. $\alpha_{1}$-Antitrypsin deficiency - 6: New and emerging treatments for $\alpha_{1}$-antitrypsin deficiency. Thorax 2004;59:904-9.

13 Shaker SB, Stavngaard T, Stolk J, et al. $\alpha_{1}$ Antitrypsin deficiency $\cdot 7$ : Computed tomographic imaging in $\alpha_{1}$-antitrypsin deficiency. Thorax 2004;59:986-91.

14 Robinson GV, Stradling JR, Davies RJO. Obstructive sleep apnoea/hypopnoea syndrome and hypertension. Thorax 2004;59:1089-94.

15 Gordon P, Sanders MH. Positive airway pressure therapy for obstructive sleep apnoea/hypopnoea syndrome. Thorax 2005;60:68-75.

16 Nixon GM, Brouillette RT. Paediatric obstructive sleep apnoea. Thorax 2005;60:511-6.

17 Ryan CF. An approach to treatment of obstructive sleep apnoea/hypopnoea syndrome including upper airway surgery. Thorax 2005:60:595-604.

18 Balfour-Lynn IM, Primhak RA, Shaw BNJ. Home oxygen for children: who, how and when? Thorax 2005;60:76-81.

19 Hessel PA, Gamble JF, McDonald JC. Asbestos, asbestosis, and lung cancer: a critical assessment of the epidemiological evidence. Thorax 2005;60:433-6.

20 Wright JL, Levy RD, Churg A. Pulmonary hypertension in chronic obstructive pulmonary disease: current theories of pathogenesis and their implications for treatment. Thorax 2005;60:605-9.

21 Burgel P-R, Nadel JA. Roles of epidermal growth factor receptor activation in epithelial cell repair and mucin production in airway epithelium. Thorax 2004;59:992-6.

22 Laurent GJ. Getting grant applications funded: lessons from the past and advice for the future. Thorax 2004:59:1010-1.

23 British Thoracic Society. British Thoracic Society guidelines for the management of suspected acute pulmonary embolism. Thorax 2003;58:470-83.

24 Henry M, Arnold T, Harvey J. BTS guidelines for the management of spontaneous pneumothorax. Thorax 2003;58:39-52.

25 British Thoracic Society. BTS guidelines for the management of community acquired pneumonia in adults. Thorax 2001;56:1-64.

26 West R, McNeill A, Raw M. Smoking cessation guidelines for health professionals: an update. Thorax 2000;55:987-99.

27 British Thoracic Society. Non-invasive ventilation in acute respiratory failure. Thorax 2002:57:192-211.

28 Laws D, Neville E, Duffy J. BTS guidelines for the insertion of a chest drain. Thorax 2003;58:53-9.

29 Maskell NA, Butland RJA. BTS guidelines for the investigation of a unilateral pleural effusion in adults. Thorax 2003;58:8-17.

30 British Thoracic Society Standards of Care Committee. The diagnosis, assessment and treatment of diffuse parenchymal lung disease in adults. Thorax 1999:54:1-28.

31 MacNee W, Calverley PMA. Chronic obstructive pulmonary disease $\cdot 7$ : Management of COPD. Thorax 2003;58:261-5.

32 Davies CWH, Gleeson FV, Davies RJO. BTS guidelines for the management of pleural infection. Thorax 2003;58:18-28.

33 Wedzicha JA, Johnston SL, Mitchell DM. Online First in Thorax. Thorax 2005;60:273. 


\section{Reviewers 1 October 2004 to 30 September 2005}

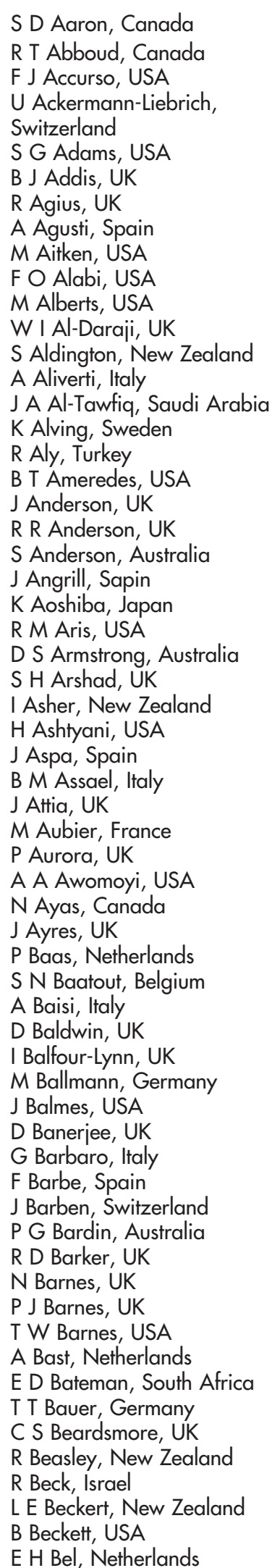

\author{
S C Bell, Australia \\ D Bellamy, UK \\ F Bellemare, Canada \\ $G$ Bellingan, UK \\ C Benden, UK \\ B G Bender, USA \\ $N$ Berend, Australia \\ R M Bernsen, UAE \\ J D Best, Australia \\ A Bhowmik, UK \\ D Bilton, UK \\ S S Birring, UK \\ P N Black, New Zealand \\ J D Blakey, UK \\ J M Bland, UK \\ F Blasi, Italy \\ A Boehler, Switzerland \\ $G$ Bolte, Germany \\ $\mathrm{H}$ Booth, UK \\ G Bothamley, UK \\ $J$ Bott, UK \\ L-P Boulet, Canada \\ J Bourbeau, Canada \\ D Bouros, Greece \\ H A Boushey, USA \\ $M$ Bower, UK \\ R P Bowler, USA \\ R J Boyton, UK \\ P L P Brand, Netherlands \\ C Braun-Fahrlander, \\ Switzerland \\ S Bretagne, France \\ C E Brightling, UK \\ C Brindicci, UK \\ J Britton, UK \\ S Brown, UK \\ $\checkmark$ Brusasco, Italy \\ R Buchdahl, UK \\ A T Burge, Australia \\ P S Burge, UK \\ P-R Burgel, France \\ C Burger, USA \\ P G J Burney, UK \\ G Burns, UK \\ A Bush, UK \\ B K Butland, UK \\ $S$ Bydder, Australia \\ C A Byrnes, New Zealand \\ E J Calderon, Spain \\ J M Calvert, UK \\ C A Camargo Jr, USA \\ M Carby, UK \\ A-L Caress, UK \\ K C L Carlsen, Norway \\ W D Carroll, UK \\ P Cassano, USA \\ R Castile, USA \\ M Cazzola, Italy \\ J C Celedon, USA \\ D S Celermajer, Australia \\ B Chakrabarti, UK \\ R C Chambers, UK
}

\author{
C K Chan, Canada \\ P Chanez, France \\ A B Chang, Australia \\ $M$ Chan-Yeung, Hong Kong \\ A J Chauhan, UK \\ Y Chen, Canada \\ N S Cherniack, USA \\ S K Chhabra, India \\ E R Chilvers, UK \\ S Chinn, UK
}

S-H Cho, Republic of Korea

F Chua, UK

F Chung, UK

A Churg, Canada

P J Ciclitira, UK

P A Cistulli, Australia

C Clark, UK

J Cleland, UK

D Cockcroft, Canada

R K Coker, UK

G L Colice, USA

D Collie, UK

A M Condliffe, UK

G J Connett, UK

S P Conway, UK

D G Cook, UK

A Coonar, UK

P Cooper, Ecuador

$M$ Corey, Canada

C J Corrigan, UK

P Corris, UK

M G Cosio, Canada

H O Coxson, Canada

J Crane, New Zealand

D D Creer, UK

P Cullinan, UK

S Cunningham, UK

E Dagli, Turkey

$M$ Daheshia, USA

S E K Dahlén, Sweden

M R Danzig, USA

A Darzi, UK

C Davidson, UK

J Davies, UK

L Davies, UK

P D Davies, UK

R J O Davies, UK

E Daviskas, Australia

P A de Jong, Netherlands

J C de Jongste, Netherlands

$R$ de Marco, Italy

A De Soyza, UK

$M$ Decramer, Belgium

E Dei Cas, France

R Dekhuijzen, Netherlands

$R$ Delfino, USA

F Della Torre, Italy

$M$ Denton, UK

F C Detterbeck, USA

K Dheda, UK

A H Diacon, South Africa

P Dilworth, UK
G Dimopoulos, Greece

R Dinwiddie, UK

A Dirksen, Denmark

R Djukanovic, UK

D Dockerell, UK

$G$ Doering, Germany

E Dompeling, Netherlands

G Donaldson, UK

K Donaldson, UK

S H Donaldson, USA

L E Donnelly, UK

J F Donohue, USA

R L Dormer, UK

N Douglas, UK

J A Douglass, Australia

I J Doull, UK

G H Downie, USA

C Dowson, New Zealand

F Drobniewski, UK

$\mathrm{R}$ du Bois, UK

M G Duerden, UK

$K$ Duncan, UK

D Dunger, UK

L Dupont, Belgium

R Dweik, USA

$J$ E Earis, UK

K M Eastham, UK

P R Eastwood, Australia

E Eber, Austria

E Edell, USA

W Eder, Germany

A M Edwards, UK

$R$ Effros, USA

$J$ J Egan, Eire

N M Eiser, UK

H M El Sahly, USA

S L Elkin, UK

$M$ Elliott, UK

P Ellwood, New Zealand

$P$ Enright, USA

P Ernst, Canada

S C Erzurum, USA

T Evans, UK

$M$ Everard, UK

C F Everett, UK

L Fairclough, UK

A Faith, UK

I Fajac, France

L Fan, USA

R Farre, Spain

D J Farrell, UK

P M Farrell, USA

B Fauroux, France

$M$ Feldmann, UK

K A Ferguson, Canada

D Fergusson, New Zealand

$M$ Ferrer, Spain

A Fisher, UK

D Fishwick, UK

J-W Fitting, Switzerland

M F Fitzpatrick, Canada

D Fleming, UK 


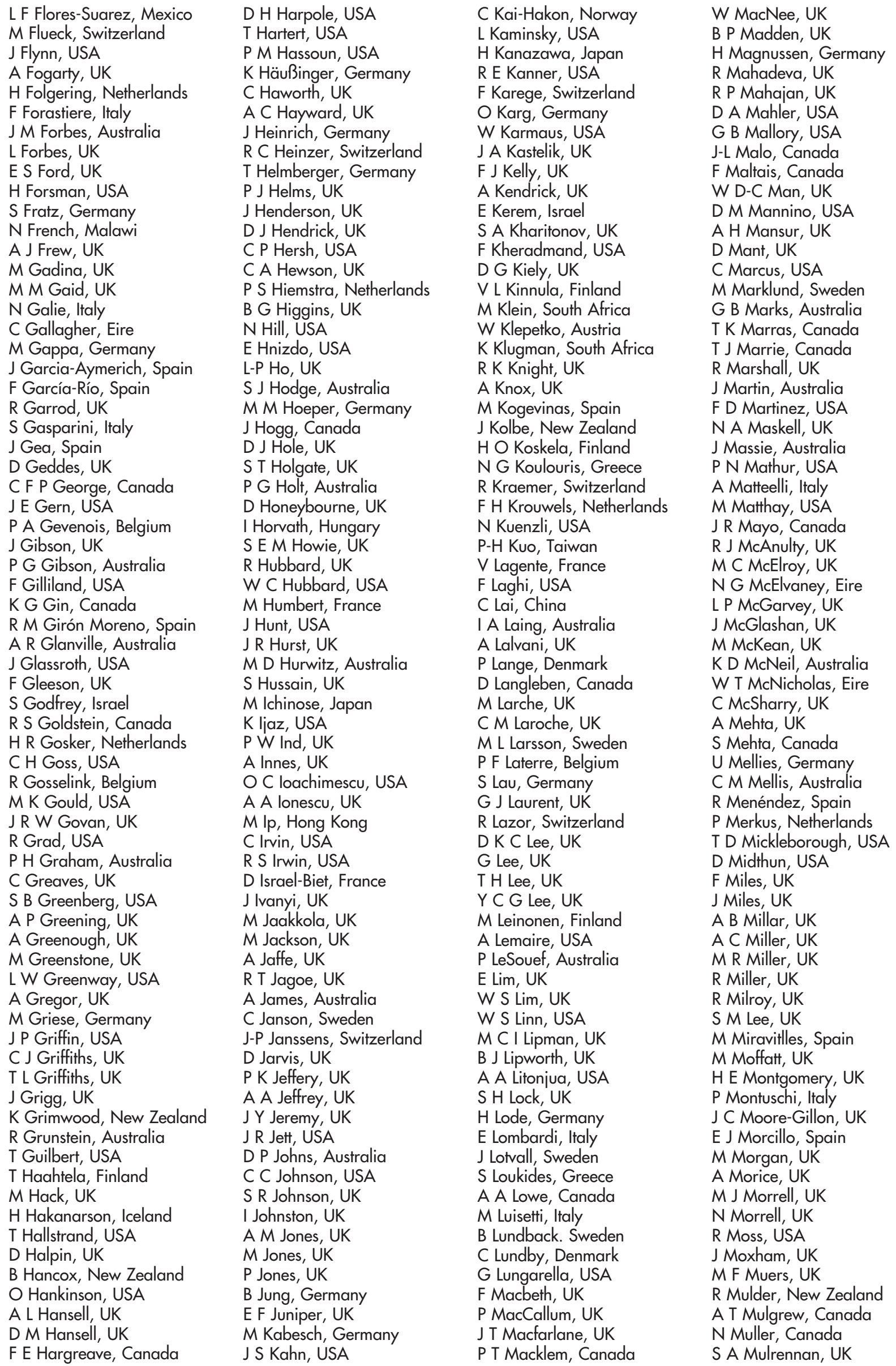


M Munavvar, UK

N Murgia, Italy

J Nadel, USA

$R$ Naeije, Belgium

$M$ Needham, UK

B Nemery, Belgium

A J Newman Taylor, UK

M J Newport, UK

T Nicolai, Germany

M S Niederman, USA

D E Niewoehner, USA

R Niven, UK

G Nixon, New Zealand

T Noah, USA

W Nystad, Norway

Y Obase, Finland

$C$ Ober, USA

P M O'Byrne, Canada

$C O^{\prime}$ Callaghan, UK

$C M O^{\prime}$ Connor, Eire

W Oddy, Australia

E Oksenhendler, France

A-C Olin, Sweden

C Ordonez, USA

I M Orme, USA

P Ormerod, UK

M Orozco-Levi, Spain

L M Osman, UK

D E Ost, USA

D N Ostrow, Canada

C Owen, USA

C Owen, UK

C Owens, UK

R D Page, UK

$P$ Palange, Italy

R J Panos, USA

A Papi, Italy

S A Papiris, Greece

J S Parmar, Canada

M R Partridge, UK

B Passlick, Germany

I S Patel, UK

J M Patel, USA

P K Pattemore, New Zealand

I Pavord, UK

D N Payne, UK

A J Peacock, UK

M D Peake, UK

N Pearce, New Zealand

M G Pearson, UK

D G Peckham, UK

C Peers, UK

J Pekkanen, Finland

R Pellegrino, Italy

J Pepke-Zaba, UK

J C T Pepperell, UK

A Perrier, Switzerland

P Pianosi, USA

J Piccirillo, USA

G Piedimonte, USA

R Piipari, Finland

E Piitulainen, Sweden

$M$ Polkey, UK

P Polos, USA

C A Pope III, USA

D S Postma, Netherlands
S Prescott, Australia

D B Price, UK

J Price, UK

R Primhak, UK

M A Puhan, Switzerland

K F Rabe, Netherlands

G F Rafferty, UK

F S F Ram, New Zealand

C Rand, USA

S Ranganathan, Australia

$G$ Redding, USA

A E Redington, UK

$C$ Reed, USA

L Restrick, UK

R L Riha, UK

R C Rintoul, UK

R Robbins, USA

$M$ Roberts, UK

R G D Roberts, Australia

D Robinson, UK

G V Robinson, UK

P Robinson, Australia

D Robiony, New Zealand

G J Rodrigo, Uruguay

E Rodriguez Becerra, Spain

R Rodriguez-Roisin, Spain

D Rogers, UK

$G$ Rohde, Germany

R J Rona, UK

$M$ Rosenfeld, USA

B H Rowe, Canada

B Rubin, USA

L Rubin, UK

I Rubinstein, USA

R Rudd, UK

A P Russell, Taiwan

$G$ Russell, UK

R Russell, UK

A Rutman, UK

C F Ryan, Canada

W Rzyman, Poland

I Sabroe, UK

R T Sadikot, USA

$M$ Saetta, Italy

J-M Sallenave, UK

J Samet, USA

J S Sampalis, Canada

A P Sampson, UK

M P Samuels, UK

$S$ Sandberg, Finland

A J Sandford, Canada

R A Sandhaus, USA

J Sastre, Spain

R C Savani, USA

S M Sawyer, Australia

GI Scano, Italy

L M Schachter, Australia

M Schatz, USA

B Schaub, Germany

B Schellenberg, Canada

S Schmitt-Grohé, Germany

B Schock, UK

AMWJ Schols, Netherlands

R Schulz, Germany

$H$ Schunemann, USA

J Schwarze, UK
N Screaton, UK

J Scullion, UK

$M$ Sears, Canada

L M Seccombe, Australia

M D Seear, Canada

T A R Seemungal, UK

N Seersholm, Denmark

S Sethi, USA

P L Shah, UK

A Sheikh, UK

D Sheppard, USA

M Shields, UK

N M Siafakas, Greece

N Sigurs, Sweden

P Silkoff, USA

$M$ Silverman, UK

E Simoes, USA

A K Simonds, UK

D D Sin, Canada

H Smit, Netherlands

D Smith, UK

A Smyth, UK

$M$ Socinski, USA

J B Soriano, Spain

D A spencer, UK

J D Spengler, USA

S Spiro, UK

R B Sporik, UK

M A Spruit, Netherlands

M C Steiner, UK

K Stenmark, UK

R D Stevenson, UK

$S$ Stick, Australia

R Stockley, UK

J Stocks, UK

J K Stoller, USA

C Strange, USA

R Strunk, USA

S Suissa, Canada

E R Sutherland, USA

C Svanes, Norway

M P Swanney, New Zealand

A Szczeklik, Poland

C C Taggart, Eire

$P$ Tam, Hong Kong

L Tanove, USA

K G Tantisira, USA

S M Tarlo, Canada

D P Tashkin, USA

A Tattersfield, UK

R Taylor, New Zealand

A Teper, Argentina

T D Tetley, UK

$M$ Thomas, UK

W R Thomas, Australia

B R Thompson, Australia

A H Thomson, UK

N C Thomson, UK

$\mathrm{H}$ Tiddens, Netherlands

$\mathrm{H} O$ Tikkanen, Finland

A Torres, Spain

T Treasure, UK

T Troosters, Belgium

W H Tsai, Canada

K W Tsang, Hong Kong

I Tsujino, Japan
G Turato, Italy

S W Turner, UK

A Turrisi, USA

$S$ Ulrich, Switzerland

C S Ulrik, Denmark

$M N$ Upton, UK

$\mathrm{P} P$ van Asperen, Australia

$O$ Van Schayck, Netherlands

T P van Staa, Netherlands

$F$ Venuta, Italy

J Vestbo, UK

E O Vianna, Brazil

M M Vitacca, Italy

$L C$ von Hertzen, Finland

J Wagener, USA

M M Wahidi, USA

C E Wainwright, Australia

S Walker, UK

C Wallis, UK

M J Walshaw, UK

$\mathrm{H}$ Walters, Australia

S Walters, UK

A Wardlaw, UK

J Weber, UK

$C$ van Weel, Netherlands

$S$ Weiland, Germany

$P$ Weller, UK

A Wells, UK

J West, UK

S D West, UK

J Wharton, UK

C G Whitney, USA

M K B Whyte, UK

$\mathrm{J} \mathrm{H}$ Widdicombe, USA

J Widdicombe, UK

J Wiggins, UK

P J Wijkstra, Netherlands

$\mathrm{H}$ Wilkens, Germany

T Wilkinson, UK

I G Williamson, UK

J Wilson, Australia

N M Wilson, UK

$R$ Wilson, UK

S R Wilson, USA

T Win, UK

W Windisch, Germany

G W K Wong, Hong Kong

R Wood-Baker, Australia

A A Woodcock, UK

$M$ A Woodhead, UK

E Wouters, Netherlands

A L Wright, USA

J L Wright, Canada

R J Wright, USA

$S$ Ying, UK

$\checkmark L$ Yu, USA

R C Yung, USA

$M$ Zach, Austria

A S Zacharasiewicz, UK

R S Zeiger, USA

D C Zeldin, UK

O Zetterstrom, Sweden

A Zumla, UK

B L Zuraw, USA 